\title{
ВИКОРИСТАННЯ ДОПОМІЖНИХ ТЕХНОЛОГІЙ У РОБОТІ 3 МОЛОДШИМИ ШКОЛЯРАМИ З РОЗЛАДОМ СПЕКТРУ АУТИЗМУ У США
}

\begin{abstract}
Псарьова М. Д.
здобувач третього (освітньо-наукового) рівня вищої освіти кафедри освітології та інноваційної педагогіки, Харківський національний педагогічний університет імені Г. С. Сковороди, м. Харків, Україна
\end{abstract}

У статті розглядаються послуги допоміжних технологій та допоміжні пристрої, які запропоновані дітям з розладом спектру аутизму у спеціальних та загальноосвітніх школах США. Серед допоміжних пристроїв нами було виділено та проаналізовано такі три групи, як низькотехнологічні, середньотехнологічні та високотехнологічні.

Ключові слова: інклюзивна освіта, розлад спектру аутизму, допоміжні технологї, США.

This article discusses assistive technology services and assistive technology devices that are offered to children with autism spectrum disorder in special and general education settings in the United States. Among the assistive technology devices, we identified and analyzed three groups, such as low-technology, medium-technology, and high-technology devices.

Key words: inclusive education, autism spectrum disorder, assistive technology, the USA.

У 2011 р. було прийнято Постанову «Про затвердження порядку організації інклюзивного навчання у загальноосвітніх навчальних закладах», згідно до якої діти з особливими освітніми потребами мають змогу навчатися разом зі своїми нормотиповими однолітками у загальноосвітніх навчальних закладах за місцем проживання [1, с. 1]. Дослідження Д.Фрикселл та К.Х.Кеннеді (D.Fryxell, C.H. Kennedy, 1995), А.Карагіанніс, В.Стеінбек та С.Стеінбек (А. Karagiannis, W. Stainback, S. Stainback, 1996), Дж.К.Гарровер та Г.Дунлап (J.K.Harrower, G.Dunlap, $2001)$ вказують на те, що інклюзивне освітнє середовище є найбільш бажаним для дитини з розладом спектру аутизму, так як воно сприяє кращому узагальненню навичок, стимулює дитину більше спілкуватися 3 однолітками 3 типовим розвитком та допомагає їй досягати більш високих академічних цілей. Адже, включення такої дитини до процесу навчання $є$ досить нелегким та тривалим через іiі проблеми взаємодії і спілкування 3 однолітками, одноманітні інтереси, особливості об- 
робки сенсорної інформації та нерідку їх проблемну поведінку [3, с. 50]. Щоб навчання та виховання такої дитини у інклюзивній школі було ефективним, вона потребує спеціальної допомоги. Одним із варіантів такої допомоги є послуги допоміжних технологій. У статті ми вважаємо необхідним зробити акцент на включення дітей з аутизмом за допомогою допоміжних технологій у американських загальноосвітніх школах, так як ця країна є одною з передових у реалізації інклюзивного навчання [4, с. 256].

Метою статті є аналіз послуг допоміжних технологій та допоміжних пристроїв для дітей з розладом спектру аутизму у спеціальних та загальноосвітніх школах Сполучених Штатів Америки.

Термін «допоміжні технології» (англ. «assistive technology») починає широко використовуватися американською психолого-педагогічною спільнотою після виходу Закону про технологічну допомогу особам з психофізичними порушеннями (англ. The Technology-Related Assistance for Individuals with Disabilities Act) від 1988 р., який став першим нормативно-правовим документом, у якому звертається увага на необхідність використання технологій під час процесу навчання дітей з особливими освітніми потребами. У законі від 2004 р. (The Assistive Technology Act) зазначено, що допоміжні технології $\epsilon$ узагальненим терміном, в основу якого входять дві складові: допоміжний пристрій (assistive technology device) та послуги допоміжних технологій (assistive technology service). Перша складова означає любий предмет, завдяки якому функціональні можливості людини з порушенням розвитку будуть значно збільшені. На прикладі дитини з аутизмом відмітемо, що такий пристрій допоможе прискорити розвиток академічних навичок, підвищити рівень володіння експресивною та рецептивною мовою та покращити поведінку. До другої складової відносяться послуги, що націлені на виявлення допоміжного пристрою. До таких сервісів The Assistive Technology Act 2004 відносить: оцінювання функціонального рівню дитини, вибір пристрою, допомога у його придбанні та налаштуванні, тренування дитини, батьків та вчителів щодо його використання [5, с. 4].

За складністю пристрою ряд дослідників (А. Г. Делл, Д. А. Ньютон, Дж. Г. Петрофф (A. G. Dell, D. A. Newton, J. G. Petroff, 2012), К. Кох (К. Koch,2017) та А. Кюхмаш (A. Qahmash,2018)) поділяють допоміжні технології на три великі групи: низькотехнологічні, се- 
редньотехнологічні та високотехнологічні [2, с. 1]. Надалі охарактеризуємо ці групи та надамо приклади допоміжних пристроїв, які використовуються для навчання дітей з розладом спектру аутизму, для кожної групи.

До першої групи відносяться низькотехнологічні пристрої, які визначаються К.Кох як «предмети, які є в наявності, недорого коштують та не мають батарей або не потребують електрики» [2, с. 1]. Для дітей 3 аутизмом до таких технологій можна віднести: візуальні підказки, які показують дитині, як поводитись у певних зонах; візуальний розклад; календар подій; альбом з індивідуальними правилами; альбом 3 картками PECS («Picture Exchange Communication System»); соціальні історії за К.Грей (C.Gray); навушники для захисту від шуму та сенсорні іграшки [4, с. 257].

Друга група - середньотехнологічні пристрої, які на думку К. Кох повинні містити батарейки або інше джерело електроенергії [2, с. 1]. До таких пристроїв відноситься: Big Button (укр., «велика кнопка»; пристрій, що дозволяє робити від однієї до трьох коротких аудіозаписів та містить місце для однієї картки), Step by Step Communicators (укр., «покроковий комунікатор»; використовується для зберігання послідовних повідомлень, які можуть бути використані у певний час доби); Go Talk (укр., «йдемо говорити»; різні за кількістю записів обладнання, які мають отвори для карток) та інші аудіозаписуючі пристрої.

Третя група технологій — високотехнологічні обладнання, до яких відноситься комп'ютер, ноутбук, планшет, смартфон та інші комп'ютеризовані пристрої. Для покращення академічних навичок, соціальної взаємодії, спілкування та регуляції поведінки може бути використані невеликі відеозаписи (video-modeling), які висвітлюють окремі актуальні для дитини теми. Також існує ряд програм, таких як Avatalker AAC та VOCA (допомагає невербальним дітям швидко повідомити про свої бажання та потреби), Speak Easy (використовується для невербальних дітей, що розуміють звернену мову, для побудови від простих фраз до складних речень), Boardmaker від Tobii Dynavox (програма для вчителів, психологів, логопедів та батьків, що дозволяє самостійно розробити матеріли для занять, які можуть бути використані у процесі навчання дітей з розладом спектру аутизму) [4, с. 257]. 
Отже, згідно до Закону про технологічну допомогу особам з психофізичними порушеннями від 1988 р. дитина з особливими освітніми потребами має отримати допоміжні технології, що включають у себе сервіси допоміжних технологій та допоміжні пристрої. У роботі з дітьми $з$ аутизмом ці пристрої націлені на покращення комунікативних навичок, допомогу дитині розвивати самостійність та регулювати небажану поведінку. За складністю такі пристрої поділяються на низьнотехнологічні (візуальний розклад, індивідуальні правила, PECS, навушники і т. д.) середньотехнологічні (Big Button, Step by Step Communicators, Go Talk та інші) та високотехнологічні (комп'ютер, ноутбук, планшет, смартфон).

\section{Список використаних джерел:}

1. Про затвердження Порядку організації інклюзивного навчання у загальноосвітніх навчальних закладах. Постанова Кабінету Міністрів України : веб-сайт. URL : https://zakon.rada.gov.ua/laws/show/872-2011$\% \mathrm{D} 0 \% \mathrm{BF} \#$ Text (дата звернення: 13.09.2021).

2. Koch K. Stay in the Box! Embedded Assistive Technology Improves Access for Students with Disabilities. Educ. Sci. 2017, 7, 82. https://www.mdpi. com/2227-7102/7/4/82/htm\#B11-education-07-00082 (дата звернення: 14.09.2021).

3. Psychiatric Association: Diagnostic and Statistical Manual of Mental Disorders, Fifth Edition. Washington, DC, American Psychiatric Association, 2013. $947 \mathrm{c}$.

4. Rotatori A. F. History of Special Education. Bingley: Emerald Group Publishing. 2011. $390 \mathrm{c}$.

5. The Assistive Technology Act: a United States law from Oct. 25, 2004. P.L. 108-364. URL: https://www.govinfo.gov/content/pkg/STATUTE-118/pdf/ STATUTE-118-Pg1707.pdf\#page=31 (дата звернення: 08.10.2021). 